\section{ON INTERGROWTHS OF HORNBLENDE WITH AUGITE IN CRYSTALLINE ROCKS.}

BY WM. H. HOBBS, MADISON, WIS.

THE question of the primary or secondary origin of hornblende in a number of types of eruptive and metamorphic rocks is one of the most difficult to answer of any that are raised by their study. The number of varieties under which the calcium magnesium iron silicates that we call hornblende occurs, makes it a somewhat difficult matter to correlate results. The term "Uralite," which Gustave Rose applied to a fibrous hornblende from the Urals, which was pseudomorphic to hornblende, has sometimes been loosely applied to any variety of hornblende which may be supposed to have this origin. Other observers have distinguished "compact hornblende" from uralite, and have also carefully stated the character of the mineral's absorption. Uralite, when applied with the proper restrictions, is always an alteration product of pyroxene. It is a matter of the commonest occurrence to find basic eruptive rocks, particularly diabase, in which the alteration of augite to this mineral can be clearly seen. As regards the compact variety, it has been described as secondary to augite by Hawes, ${ }^{1}$ Irving and Van Hise, ${ }^{2}$ and Williams. ${ }^{3}$

In the beautiful monograph on the "Eruptive Rocks of Electric Peak and Sepulchre Mountain, Yellow stone National Park," ${ }^{4}$ Professor J. B. Iddings devotes considerable space to the description of very interesting intergrowths of augite and hornblende, both in diorites and glassy rocks. The author uses the opportunity to raise a strong doubt as to the secondary nature of compact hornblende in those cases in which it has been described. Because of

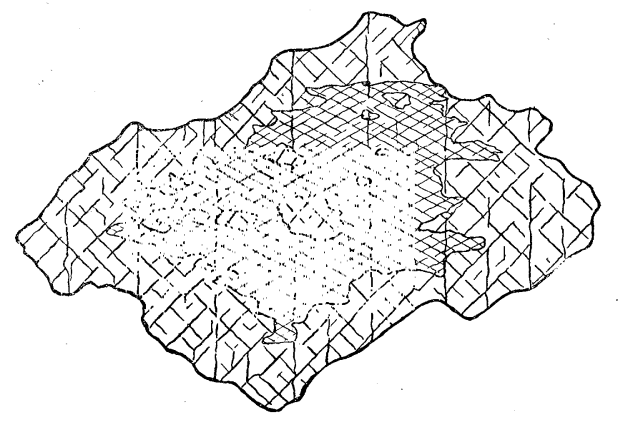

the deservedly wide reputation of Professor Iddings, his generalizations regarding this point will be received with much consideration. It has seemed to the present writer that Mr. Iddings should have made mention of earlier descriptions of intergrowths of these minerals where the primary nature of the hornblende has been as clearly demonstrated as in the cases he describes.

Parallel intergrowths of augite and hornblende have been frequently observed in eruptive rocks. Teall, ${ }^{5}$ Rohrbach, ${ }^{6}$ myself, and probably others have figured them. Rohrbach described intergrowths in a teschenite, from the Teufelsgrund, in which the hornblende has its own outlines and is sharply outlined from augite. Chemical analysis show ed an essential difference in com position between the augite and hornblende. I have described very similar growths in the augite diorite from Medford in Massachusetts. Here the hornblende is the brown variety and the augite the pink variety common in diabases. That the hornblende is primary is shown not only by its idiomorphic character, but also by the fact that the augite is sometimes almost entirely altered to clorite, the hornblende remaining fresh. Professor Iddings's

1 Mineralogy and Lithology of New Hampshire, Plate vil., Fig. 1.

2 Geology of Wisconsin, 1ii, 170; iv., 662. American Journal of Science (3), xxvi., 29 .

3 Ibidem, xxvili., 259-268.

4 Extract from the Twelfth Annual Report of the Director of the U. S. Geological Survey.

${ }^{5}$ Quarterly Journal of the Geological Society, London, xl.. 653, Plate xxix., Fig. 3

- Ueber die Eruptivasteine in Gebiete der zchlesischen-mährischen Kreidefurmation. Min. u. petrog. Mitth., vil., 24, Plate i., Figs. 1-7.

7 On the Petrographical Characters of a Dike of Diabase in the Boston Basin. Bull. Comp. Zoöl., Harv. Coll., xvi., 10, Plate i., Flg. 2 . conclusions will doubtless go far toward correcting any tendency to describe compact hornblende as secondary when the principal basis for it is the analogy with uralite, as his observation of an instance of hornblende altered to augite brings into the study of the relations of these minerals a new complication.

I have recently observed some rather unusual interorowths of augite and hornblende in a rock from the "Cleveland Gold Mine" in New Marlboro, Mass. The rock is largely composed of these minerals, but is slightly calcareous and is apparently a phase of crystalline limestone. Nearly all the crystals represent intergrowtbs, the hornblende generally predominating and enclosing the augite, which is of irregular outline and oriented like the hornblende. Prismatic sections show a wide divergence in the extinction angles, and the hornblende is light-green and pleochroic, while the augite is almost colorless. The intergrowth figured is interesting because the augite in this instance completely surrounds the hornblende, a structure that $I$ think is rare, as $I$ have not seen it described. The section is nearly perpendicular to the $c$ axis, since the cleavage angle in the augite was measured as $89^{\circ}-90^{\circ}$, and that of the hornblende as $125^{\circ}$. While sharply contrasted by differences in their color and cleavage angle, the two minerals are more markedly distinct in polarized light. I bave noticed other instances of intergrowths of these minerals within the same area, but this is the only one where hornblende was seen to be entirely enclosed by augite.

An examination of the section figured will show how intricate is the intergrowth. Islands of augite are enclosed within the hornblende. A somewhat pronounced parting parallel to the clino-pinacoid passes through both minerals. There seems to be considerable similarity between intergrowths of these minerals and the quartz which is so often enclosed within the feldspar of pegmatites. The bornblende, like the feldspar, is most frequently the enclosing mineral, and in the instance described by Rohrbach it is, like the feldspar, the more basic of the two minerals.

\section{OPTICAL ANGLE AND ANGULAR APERTURE.}

BY ALFRED C. LANE, MICHIGAN MINING SCHOOL, HOUGHTON, MICH.

THE observation of the brilliantly-colored images which are given by various crystals, natural and artificial, in polarized light is of considerable diagnostic value. The apparent breadth between the two branches of the hyperbola which may be seen in the image given by many biaxial substances, e.g., white mica, is dependent upon the optical angle,-a constant characteristic of them. The relation between this breadth and the "optical angle in air" (2E) is usually found by noting the apparent breadth in the case of a plate whose optical angle is somehow otherwise known (see Iddings's translation of Rosenbusch's "Microscopic Physiography," also Czapski in the Neues Jahrbuch für Mineralogie, etc., 1892, supplementary vol. vii.).

I wish to describe briefly the very simple method that I use for determining said relation, which also may be used to determine the angular aperture of the objective.

It works well in class, and the only reason why it has not long ago been adopted seems to be that the German microscopes on which the technique of the subject has been developed are not built to admit of it. But any microscope whose mirror bar is graduated to measure the obliquity of the light will do.

We will suppose, then, that we have such a microscope, that above and below our plate of mica we have nicols, below it a strong condensor, and above a short-focus objective.

We may use a camera and project the image with its hyperbola on paper, but we will suppose that instead of that we use a Bertrand lens. which slips into the tube between eye-piece and objective, and with the former makes a compound microscope which magnifies the image given by the objective alone. We will also use a micrometer eye-piece. To measure the distance between the hyperbola branches, the micrometer scale must run diagonally. After noting the position of the branches on the scale, turn it till it runs right and left, the same way that the mirror swings. Then, without altering the distances between Bertrand lens, objective, and eye-piece, lower the whole tube until the front of the 
objective is down to the axis about which the mirror rotates. Use the plane side of your mirror, and reflect the image of a distant object. e g., a dot on a window-pane, which must also be in the line of the axis of the mirror's rotation, into the field of view so that the aforesaid dot will appear in the centre if the mirror is directly beneath.

If all is properly adjusted, on moving the mirror-bar to and fro, the dot will always appear reflected from the centre of the mirror. The angle through which the mirror-bar must be swung, so that the image of the dot may be first where the apex of one branch of the hyperbola was and then where the other apex was, will be the optical angle in air (2E). The angle, which may be swung from where the dot disappears on one side to where it disappears on the other, will give the angular aperture of the objective used.

\section{SUBDIVISIONS OF THE AZOIC ARCHAEAN IN NORTHERN MICHIGAN.}

By M. E. WAdSWORth, State GeOlogist, houghton, Mich.

THE work of the Michigan Geological Survey in 1890 made it clear that the Azoic system of the Lake Superior district of northern Michigan was composed of at least three unconformable formations. This conclusion was published by me early in 1891, in an article entitled "A Sketch of the Geology of the Marquette and Keweenawan Districts," which was appended to a pamphlet called "Lake Superior - Along the South Shore," New York, 1891. These general conclusions have been confirmed by the work of the two subsequent seasons, and two other unconformable formations rendered probable, although not yet proved conclusively. A discussion of these points will subsequently be given in detail in the reports of the State geologist.

The following are the formations as made out and named from prominent localities by the Michigan Survey, commencing with the oldest. There are given with this the formations as determined by the United States Geological Survey, showing their supposed equivalency.

\begin{tabular}{|c|c|c|c|}
\hline \multicolumn{3}{|r|}{ Michigan Geological Survey } & U. S. Geological Survey. \\
\hline $\begin{array}{l}\text { di } \\
\frac{8}{* 0}\end{array}$ & Laurentian (?) Period. & Cascade Formation. & Fundamental Complex. \\
\hline 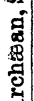 & Huronian (?) Period. & $\begin{array}{l}\text { Republie Formation. } \\
\text { Mesnard Formation. }\end{array}$ & Lower Marquette Series. \\
\hline $\begin{array}{l}0 \\
0 \\
0 \\
0 \\
0\end{array}$ & Michigan Period. & $\begin{array}{l}\text { Holyoke Formation. } \\
\text { Negaunee Formation. }\end{array}$ & Upper Marquette Series. \\
\hline
\end{tabular}

POTATO SCAB.

BY H. L. BOLLEY, FARGo, No. DAKOTA.

THIs disease of the potato-tuber need not longer mar the appearance. quality, and economic value of the crop. The corrosive sublimate treatment, recommended in Bulletin No. 4, of North Dakota Experiment Station, has had another year's trial, not only at this station but by potato-growers, and it has again proven effective in a degree beyond previous expectation. Though the damage done each year by this disease is so great and widespread in its occurrence, no plant-disease now successfully combated is so easily prevented and at such a slight cost.

As indicated in my work of previous seasons, it is again demonstrated this past season that the damage to the yield of the crop is very much in excess of that usually supposed. The disease attacks not only the tubers but the base of the vines also; the result is a shorter-lived vine, a greater number of potatoes set upon the vines than there would be under normal conditions, and, third, much smaller tubers. The second of these statements, perhaps, needs some explanation. I have only one to offer, which I think to be about the correct one, i. e., the disease early attacks the young tubers as they set upon the vines, normal growth is checked, and the excess of vigor in the vines which is at its highest stage at this time finds expression in the formation of new tubers to the further detriment of those already set upon the stems.

The results of this summer's work when averaged for all tests show an average gain of one-half pound per hill in favor of the treated seed-tubers, and 99.33 per cent of total product void of disease; while untreated seed in all cases gave a product in which less than one per cent undiseased tubers were found.

- The cost of treatment for a crop of two or three acres of potatoes need not exceed fifty cents, aside from that of one or two days' extra labor.

Details of the season's work will soon appear in bulletin form.

THE fourteenth edition of Franklin Leonard Pope's "Modern Practice of the Electric Telegraph" has just appeared (D. Van Nostrand Company, 234 p., $8^{\circ}, \$ 1.50$ ). This is a teehnical handbook for electricians, managers, and operators, and contains 185 illustrations. As this book has been a standard authority on telegraphy for almost a quarter of a century, it is unnecessary to say anything to those already familiar with it, except that it has been rewritten, enlarged, and brought to date. To others, it is sufficient to repeat that this is the fourteenth edition of a comprehensive and handsomely illustrated work.

- The Johns Hopkins University has published a large geological map of the vicinity of Baltimore, prepared by Professor G. H. Williams. It is an extension of a similar map prepared by Williams and Darton and published by the U. S. Geological Survey some months ago; but the coloring on the present issue departs from the color system adopted for the Survey maps; as if experimentally to try another device, better applicable to the region here included. The experiment is successful; but it does not follow from this isolated instance that the color scheme of the Survey should be changed in its uniform application to the great series of maps for which it was prepared.

- The Geological Survey of Missouri, Arthur Winslow, director, has issued an atlas report on the Higginsville map-sheet, with two colored maps and several papes of text, chiefly concerning the coal measures of the region. The large form of the report avoids the difficulty of folding the maps, which constitute its chief feature; but the size of the atlas is inconveniently large for easy keeping in the library or on the desk. As a forerunner, however, of what we shall have to deal with when the publication of similar atlases of maps and texts is begun by the U.S. Geological Survey, the Higginsville atlas gives us useful practice. The extension of such a series of reports to include the other mapsheets of Missouri will add greatly to our information about that State.

- Professor F. A. Forel of Morges, Switzerland, has long been known as a careful investigator of the natural history of Lake Geneva, on whose borders he was born and bred. Several years ago he published a small pocket volume on the various features of the lake; and now we receive from Rouge of Lausanne the first of three volumes, entitled "Le Léman; Monographie Limnologique." Judging the whole work by what now appears, as well as by the high standard of Forel's previous writings, it is not too much to say that it will take an eminent place among scientific monographs, ranking with Favre's "Alps of Savoy" and Heim's "Mechanism of Mountain-Making." The division of the present volume which will excite most general interest is the serious discussion of the origin of the lake, from which Forel concludes that, of all suggestions, the one which ascribes the basin to the warping of a pre-existent valley is by far the most probable. The winds of the lake are fully described; but in the excursions in connection with them into the theory of cyclones and anticyclones, the author evidently ventures into a field somewhat unfamiliar to him; his suggestions on this subject not being made in view of all that is known about it. The second volume will include an account of the seiches, or oscillations, of which Forel has already written so much; the third will discuss the biology of the lake and its human antiquities. An excellent map accompanies the first volume. 